\title{
「カテーテル手術の外科と麻酔一安全な低侵襲手術の確立を 目指して一」によせて
}

小出康弘 ${ }^{* 1}$ 黑川 智*2

このシンポジウムでは, 心臓血管領域のカテーテ ル手術に焦点をあて, 各カテーテル治療を術者と麻 酔科の両者の立場からの講演をいただいた，東京女 子医科大学チームからはステントグラフト内挿術と 小児心臓カテーテル治療を, 湘南鎌倉総合病院チー ムからは経カテーテル大動脈弁留置術をテーマとし ていただいた。ステントグラフト内扦術は日本にお いて保険適用されたのが, 腹部大動脈が2006年, 胸部大動脈が2008年である。現在では大動脈瘤の 治療のファーストラインの位置づけとなっている. また，2013年 10 月に保険適用された経カテーテル 大動脈弁留置術は本邦での実施数が 1,000 例を超え ている.

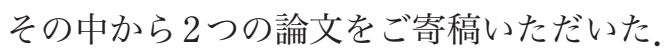

湘南鎌倉総合病院の山中太先生の「経カテーテル 大動脈弁留置術一術者の視点から一」で, 日本での 初期成績(PREVAIL Japan) と Massy からのレジスト リーのデータ比較から，フランス人と比較して対象 となった日本人の体格は小さいことがわかる. Massy のデータでは, 小さな体格 $\left(\mathrm{BSA}<1.75 \mathrm{~m}^{2}\right)$ は有意 に主要血管合併症の発生頻度が多くなっている。日
本の PREVAIL Japan では, 小さな体格(平均 $1.41 \mathrm{~m}^{2}$ ) にもかかわらず，主要血管合併症が $6.3 \%$ と抑えられ ている。デリバリーシステムの改善は主要血管合併 症を低下させることが示されていたが1), SAPIEN XTでも $11 \%$ の頻度があることが報告されており， 日本での手技の丁寧さが認められた結果であると考 えられた。

東京女子医科大学の黒川智先生の「小児心臓力テ 一テル治療 : 麻酔科医の視点から」では, 各種カテ ーテル手技のリスクカテゴリー分類が紹介されてお り, 麻酔計画を立案する上で有用な情報になると思 う。また麻酔薬選択に関する比較論文が詳細に揭載 されていて，小児 monitored anesthesia careにおけ る理想的な麻酔薬選択について言及している点が興 味深い.

\section{参考文献}

1) Mussardo M, Latib A, Chieffo A, et al. : Periprocedural and short-term outcomes of transfemoral transcatheter aortic valve implantation with the Sapien XT as compared with the Edwards Sapien valve. JACC Cardiovasc Interv $4: 743-750,2011$ \begin{tabular}{l}
\hline${ }^{* 1}$ 葉山ハートセンター・湘南鎌倉総合病院麻酔科 \\
$* 2$ 東京女子医科大学医学部麻酔科学教室
\end{tabular}
著者連絡先 小出康弘

干 240-0116 神奈川県三浦郡葉山町下山口 1898-1 葉山ハートセンター麻酔科 